УДК 378.04:7.012]:005.336.2

DOI: https://doi.org/10.33989/2075-146x.2019.24.194634

\title{
ЛАРИСА ГРИЦЕНКО
}

ORCID ID /0000-0003-0366-9386

Полтавський Національний педагогічний університет імені В.Г. Короленка

ЛЮДМИЛА СТРАШКО

ORCID ID 0000-0003-0862-3766

Полтавський університет економіки і торгівлі

\section{ВЗАЄМОЄВ'ЯЗОК ХУДОЖНЬО-ГРАФІЧНОЇ ТА ПРОФЕСІЙНО-ПЕДАГОГІЧНОЇ КОМПЕТЕНТНОСТЕЙ У ПІДГОТОВЦІ ФАХІВЦІВ ТЕХНОЛОГІЙ І ДИЗАЙНУ}

\begin{abstract}
У статті проаналізовано особливості та проблеми формування сучасної художньо-графічної компетентності фахівців технологій і дизайну. визначено і розкрито шляхи ії формування у майбутніх фахівців технологій і дизайну як складника їхньої професійно-педагогічної компетентності. Обгрунтовано необхідність урахування взаємозв'язку художньо-графічної та професійно-педагогічної компетентностей у підготовці майбутніх фахівців технологій і дизайну.

Наукова новизна дослідження полягає в розробці структурно-логічноґо механізму взаємозв'язку художньо-графічної і професійно-педагогічної компетентностей. Практичне значення дослідження полягає у визначенні напрямів удосконалення організації теоретичної і практичної підготовки фахівців технологій і дизайну через виконання системи творчих завдань, спрямованих на розвиток як художньо-графічної, так і професійно-педагогічної компетентностей.
\end{abstract}

Ключові слова: художньо-графічна компетентність; професійна компетентність; професійнопедагогічна компетентність; професійно-педагогічна спрямованість

Постановка проблеми. Однією із цілей реформування вищої освіти $є$ підвищення якості підготовки майбутнього фахівця. Пріоритетними поняттями $\epsilon$ поняття компетентності фахівця, галузевих компетенцій. Закладено основи теоретичної бази по реалізації завдань компетентнісного підходу в освіті (А. Іщенко, М. Карпенко, I. Радигіна, О. Корсаков, В. Кушнір, О. Пометун, О. Часнікова та ін.). Законодавчі документи тлумачать поняття професійної компетентності достатньо глибоко: «Професійна компетентність - здатність особи в межах визначених за посадою повноважень застосовувати спеціальні знання, уміння та навички, виявляти відповідні моральні та ділові якості для належного виконання встановлених завдань і обов'язків, навчання, професійного та особистісного розвитку» Про державну службу. Закон України від 10.12.2015 № 889-VIII); «Професійна компетентність - динамічна комбінація знань, умінь, навичок, цінностей, інших особистих якостей, що визначає здатність особи успішно здійснювати професійну діяльність та/або подальшу навчальну діяльність» Про затвердження Положення про проходження первинної професійної підготовки та підвищення кваліфікації особами рядового і начальницького складу Державної кримінально-виконавчої служби України. Наказ Міністерства юстиції України; Положення, Форма типового документа, Сертифікат, Картка від 26.12.2018 № 4091/5); «Професійна компетентність - здатність учасника професійного навчання в межах визначених за посадою повноважень застосовувати спеціальні знання, уміння та навички, виявляти відповідні моральні та ділові якості для належного виконання встановлених завдань i обов'язків, навчання, професійного та особистісного розвитку». Про затвердження Положення про систему професійного навчання державних службовців, голів місцевих державних адміністрацій, їх перших заступників та заступників, посадових осіб місцевого самоврядування та депутатів місцевих рад Постанова Кабінету Міністрів України; Положення, Перелік від 06.02.2019 № 106).

Результати аналізу психолого-педагогічної літератури з досліджуваної проблеми дали змогу виявити низку суперечностей між :

- традиційними підходами до професійної підготовки майбутніх фахівців та необхідністю використання під час навчання сучасних методологічних засад, що сприяють формуванню їхньої професійної компетентності;

- упровадженням компетентнісного підходу в систему сучасної вищої освіти та низьким рівнем обізнаності фахівців щодо його застосування;

- потребою використовувати новий зміст освіти у професійній діяльності вчителя технологій і креслення та відсутністю методик формування у студентів готовності до реалізації завдань професійно-педагогічної компетентності та навичок впровадження іiі в процес розв'язання професійно-зорієнтованих завдань;

- хибне розуміння ролі автономізації вишів у створенні навчальних планів низки спеціальностей.

Мета статті - дослідити доцільність урахування взаємозв'язку художньо-графічної компетентності із професійно-педагогічною компетентністю у підготовці фахівця технологій і дизайну.

Виклад основного матеріалу. Незворотність характеру освітніх зрушень у суспільстві вказує на те, що процес усвідомлення цінностей педагогічної діяльності добігає кінця і приходить розуміння, що професія вчителя не може ставитись на один щабель із іншими професіями. Про це свідчить прагнення молоді вчитися не для отримання високої заробітної плати, а набуття якісних професійних навичок. Не знаходячи таких вишів на батьківщині, абітурієнти звертаються до закордонних навчальних закладів. Адже автономізація вишу у нас часто розуміється як 
можливість зміни навчальних планів на власний розсуд, що деформує поняття професійної та професійнопедагогічної компетентності. Саме компетентнісний підхід розглядається як один із важливих концептуальних принципів сучасної методології оновлення освіти.

Поняття «компетентність» (лат.competens - відповідний, здібний) означає коло повноважень будь-якої посадової особи чи органу; володіння знаннями, досвідом у певній галузі. Під професійною компетентністю педагога розуміють особистісні можливості учителя, які дозволяють йому самостійно i ефективно реалізувати цілі педагогічного процесу. Для цього потрібно знати педагогічну теорію, уміти застосовувати іiі в практичній діяльності. «Компетентність» визначає рівень професіоналізму особистості, а ії досягнення відбуваються через здобуття нею необхідних компетенцій, що є метою професійної підготовки фахівців (Банашко, Севастьянова, Крищук, \& Тафінцева, 2019).

Згідно з даною концепцією, під компетенціями розуміється сукупність взаємозалежних якостей особистості (знання, уміння, навички, способи діяльності), необхідних для якісної продуктивної діяльності. Компетентність визначається як володіння відповідними компетенціями. Аналіз визначень педагогічної компетентності дає змогу стверджувати, що педагогічна компетентність є системою наукових знань, інтелектуальних і практичних умінь і навичок, особистісних якостей і утворень, яка при достатній мотивації та високому рівні професійності психічних процесів забезпечує самореалізацію, самозбереження та самовдосконалення особистості педагога в процесі професійної діяльності.

Професійно-педагогічна компетентність вчителя $\epsilon$ «складною багаторівневою стійкою структурою його психічних рис, що формується внаслідок інтеграції досвіду, теоретичних знань, практичних умінь, значущих для вчителя особистісних якостей і має окреслені суттєві ознаки ( мобільність, гнучкість і критичність мислення (Банашко, Севастьянова, Крищук, \& Тафінцева, 2019).

Розлядаючи сутність професійно-педагогічної конкурентоздатності, слід визнати феномен професійнопедагогічної спрямованості - спрямованість на особистість учня. Професійно-педагогічна спрямованість досліджувалася вченими Н. Кузьміною, А. Ахмедзяновою, Т. Томіловою, С. Вітвицькою, С. Яремчук та ін. Феномен професійно-педагогічної спрямованості психологи трактують як систему особистісних якостей, які визначають стійке, усвідомлене, активно-дійове ставлення до педагогічної праці. За визначенням М. Дьяченка і Л. Кандибовича, професійно педагогічна спрямованість - це розуміння і внутрішнє прийняття мети й завдань професійної діяльності, iii інтересів, ідеалів, настанов, переконань, поглядів, що характеризуються «стійкістю (нестійкістю), домінуванням суспільних або вузькоособистісних мотивів, далекою або близькою перспективою» (Дьяченко, \& Кандибович, 1981). С. Яремчук виділяє як компонент педагогічної спрямованості професійно-психічну спрямованість. Під професійно-психічною спрямованістю майбутнього вчителя вона розуміс «таке динамічне психічне утворення, яке характеризується усвідомлюваними особистістю домінуючими професійними мотивами, що визначають стійке, тривале, активно-дійове позитивне ставлення особистості до опанування психологічних знань, умінь, навичок, i забезпечує ефективність виконання виховних, освітніх і розвивальних завдань у майбутній професійній діяльності» (Яремчук, 2001).

Вітвицька С. С. пропонує досліджувати два аспекти у педагогічній діяльності: особистісний та процесуальний: «Перший, особистісний, - це сукупність тих домінуючих форм особистісної спрямованості майбутнього вчителя, що спричинюють його вираження. Складовими цього аспекту є: потреби (в досягненні професійно-педагогічної мети, педагогічному спілкуванні, професійному самовираженні, самопізнанні), що обумовлюють професійно значущу мотивацію; інтерес (до програмних і позапрограмних психолого-педагогічних знань, до себе самого та інших людей i, зрештою, до професії вчителя); ідеали (наслідування педагога-«ідеала», прагнення до професійного вдосконалення, «еталонного» рівня вчителя); переконання в потребі й важливості психолого-педагогічних знань, навичок та вмінь для успішної діяльності; рівень домагань (складність педагогічних завдань); самооцінка (загальноосвітня та професійна); ціннісні орієнтації, життєва мета тощо» (Вітвицька, 2003).

На наш погляд, визначаючи феномен професійно-педагогічної спрямованості, концептуально важливо враховувати фактори мотивів, інтересу, потреб, здібностей до цієї специфічної діяльності. У педагогічній діяльності не можна ставити знак рівняння між поняттями компетентність і кваліфікація. Професійно-педагогічна компетентність носить інтегрований характер і об'єднує професійні знання, інтелектуальні навички і вміння i специфічні способи діяльності, адже професійне становлення передбачає оперування комплексами моделей розумової діяльності, оволодіння прийомами і методами педагогічного мислення і готовність до їх рефлексивної переробки. У сучасній педагогічній карті світу названо 16 складових педагогічної компетентності: орієнтація на результат діяльності учня; цінність знання, орієнтованого на потреби життя; орієнтація на збереження традицій, адаптацію особистості; центрація на діяльності; фокус на індуктивних способах здобування знань; опора на когнітівний процес; опора на зовнішній стимул діяльності; орієнтація на індивідуально-особистісний розвиток; орієнтація на процес; цінність формального, фундаментального знання; орієнтація на керовану зміну майбутнього; центрація на дяльності учня; фокус на передачі готових знань і досвіду; опора на поведінку; опора на внутрішній стимул діяльності.

Згадуючи твердження великого Я. А. Коменського про те, що педагогіка є мистецтвом, додаємо до структурних компонентів педгогічної компетентності педагогічні почуття, без яких неможлива взаємодія учителя і учня та відповідальність за іï результати. Ми погоджуємося із О. П. Рудницькою, яка змалювала механізм світовідчуття, світосприймання, світоспоглядання, світорозуміння: «під впливом художніх образів безпосередні почуття переходять в естетичні, етичні уявлення, цінності. Художнє світобачення стає внутрішнім змістом суб'єкта, індивідуальний досвід розширюється, збагачується; почуття, смаки і потреби набувають культурно-естетичної форми» (Рудницька, 2005, с. 50).

Відтак, звертаючись до критеріїв освіченої людини, бачимо перелік культурологічних цінностей, які повинен розвивати (а не «давати») педагог: «вміння вчитися, вміння орієнтуватися у людському світі, потреба самоосвіти і саморозвитку», «cultura» у педагогічному контексті означає освіта, навчання, виховання». Розглядаючи складові 
елементи освітнього вектору художньо-графічної підготовки студентів, відмічаємо, що філософсько-педагогічні позиції вчених І. А. Зязюна, Л. О. Хомич, О. Шевнюк та ін. переконують, що підготовка майбутніх учителів повинна відбуватись на основі засвоєння багатств художньої культури і ціннісних пріоритетів, які лежать в основі національної культури. А з точи зору популярного нині синергетичнго підходу у дослідженнях усі види мистецтва мають одне коріння.

На думку І. Ревенко, художньо-графічну компетентність можна розглядати багатоаспектно, а саме: як певний обсяг культурно-історичних і художньо-графічних знань; як уміння й навички художньо-естетичного сприймання, аналізу й інтерпретації творів мистецтва відповідно до авторського задуму, розуміння єдності форми і змісту; як прагнення i здатність реалізувати на практиці художньо-естетичний потенціал для одержання власного неповторного результату творчої діяльності (Ревенко, 2007, с. 140).

Позицію щодо сутності художньої компетентності висловлюють у своїх працях Г. Гогоберідзе, Л. Кпикова, Л. Масол, Л. Михайлова та інші науковці. Так, на думку В. Ананьєвої (Ананьева, 2013). До складу художньої компетентності вчителів входить низка компетенцій, а саме: 1) образотворчо-мовленнєва (здатність створювати образи засобами художньої виразності);

2) вербально-образна (знання й розуміння художніх термінів і вміння їх використовувати при обговоренні творів мистецтва); 3) образно-стильова (знання стильових напрямів у мистецтві, уміння оперувати ними);

4) стратегічна (допитливість, гнучкість мислення); 5) продуктивно-образна (здатність відтворювати образ, творчо вирішувати завдання).

Аналіз теоретичної бази досліджуваної проблеми дозволив нас прийти до висновку, що художньо-графічна компетентність - це інтеграційна властивість особистості, особливе психологічне формування, яке визначає емоційно-естетичну спрямованість і активність особистості, іiі здібність до художньо-образного освоєння середовища за допомогою графічних методів і засобів, а також його втілення в духовному плані або реально предметному матеріалі.

Отже, дослідивши структуру художньо-графічної та професійно-педагогічної компетентностей, можемо побачити діалектичні взаємозв'язки - процеси впливу різних об'єктів один на одного, їх взаємообумовленість, зміну стану, взаємоперехід, а також породження одним об'єктом іншого (див. табл. 1).

Таблиця 1

\section{Взаємозв'язок художньо-графічної і професійно-педагогічної компетентностей}

\begin{tabular}{|l|l|l|l|}
\hline № & $\begin{array}{l}\text { Категорія } \\
\text { взаємозв’язку }\end{array}$ & Художньо-графічна компетентність & Професійно-педагогічна компетентність \\
\hline 1. & Ціль & Формування особистості фахівця & Формування особистості вчителя \\
\hline 2. & Принципи & Гуманізму, демократизації, саморозвитку & Гуманізму, демократизації, саморозвитку \\
\hline 3. & Зміст & Національна культура & Національні цінності \\
\hline 4. & Засоби & Творчі почуття & Творчі почуття \\
\hline 5. & Функції & Світоглядні & Світоглядні \\
\hline
\end{tabular}

В основі запропонованої моделі взаємозв'язків художньо-графічної та професійно-педагогічної компетентностей лежить методологічний шлях формування особистості фахівця від художньо-графічної компетентності через отримання певного рівня професійно-педагогічної культури як виявлення професійного світогляду (симбіоз фахових знань, особистісних переконань і професійної діяльності). Розроблену авторами структурно-логічну модель взаємозв'язку художньо-графічної і професійно-педагогічної компетентностей покладено в основу методичних матеріалів для навчального процесу майбутніх фахівців технологій та дизайну.

Висновки. Отже, у статті проаналізовано психолого-педагогічну літературу з питань художньо-графічної та професійно-педагогічної компетенцій; розглянуто їх структуру; обгрунтовано необхідність розгляду взаємозв'язків художньо-графічної та професійно-педагогічної компетенцій як частини і цілого в єдиному педагогічному процесі формування особистості фахівця технологій і дизайну.

\section{Список використаних джерел}

Ананьева, В. (2013). Особенности развития художественно-творческой компетентности старших дошкольников. Взято c https://scienceforum.ru/2013/article/2013006567/.

Банашко, Л. В., Севастьянова, О. М., Крищук, Б. С., \&Тафінцева, С. І. (2019). Концепиія педатотічної компетентності майбутніх учителів у системі ступеневої підготовки спеціалістів початкової ланки освіти. Хмельницький: Хмельницька гуманітарно-педагогічна академія. Взято з http://www.kgpa.km.ua/?q=node/233.

Вітвицька, С. (2003). Педагогічна спрямованість як компонент професійної майстерності майбутніх вчителів. Вісник Житомирського державного педагогічного університету ім. І. Франка, 12, 78-81.

Дьяченко, М., \& Кандибович, П. (1981). Психология высшей школы. Минск: Из-во БГУ.

Про державну службу: Закон України № 889-VIII (10.12.2015). Взято з https://zakon.rada.gov.ua/laws/show/889-19.

Про затвердження Положення про проходження первинної професійної підготовки та підвищення кваліфікації особами рядового і начальницького складу Державної кримінально-виконавчої служби України: наказ Міністерства юстиції України № 4091/5 (26.12.2018) Взято з https://zakon.rada.gov.ua/laws/show/z1496-18. 
Про затвердження Положення про систему професійного навчання державних службовиів, голів місиевих державних адміністрачій, їх перших заступників та заступників, посадових осіб місиевого самоврядування та депутатів місцевих рад: постанова Кабінету Міністрів України № $106 \quad$ (06.02.2019). Взято 3 https://zakon.rada.gov.ua/laws/show/106-2019-\%D0\%BF.

Ревенко, I. (2007). Художньо-естетична компетентність учителя як показник його професійної культури. Мистеитво $i$ ocвima, 3, 139-146.

Рудницька, О. (2005). Педагогіка: затальна та мистецька. Тернопіль: Навчальна книга.

Яремчук, С. (2001). Професійно-психологічна спрямованість особистості майбутнього вчителя. Педагогіка $і$ психологія, $1(30), 89-97$.

\section{References}

Anan'eva, V. (2013). Osobennosti razvitija hudozhestvenno-tvorcheskoj kompetentnosti starshih doshkol'nikov [Features of development of artistic and creative competence of senior preschoolers]. Retrieved from https://scienceforum.ru/2013/article/2013006567/ [in Russian].

Banashko, L. V., Sevastianova, O. M., Kryshchuk, B. S., \&Tafintseva, S. I. (2019). Kontseptsiia pedagogichnoi kompetentnosti maibutnikh uchyteliv u systemi stupenevoi pidhotovky spetsialistiv pochatkovoi lanky osvity [The concept of pedagogical competence of future teachers in the system of stage training of specialists in elementary education]. Khmelnytskyi: Khmelnytska gumanitarno-pedagogichna akademiia. Retrieved from http://www.kgpa.km.ua/?q=node/233 [in Ukrainian].

D'jachenko, M., \& Kandibovich, P. (1981). Psihologija vysshej shkoly [Psychology of higher education]. Minsk: Iz-vo BGU [in Russian].

Pro derzhavnu sluzhbu [About the civil service]: Zakon Ukrainy № 889-VIII (10.12.2015). Retrieved from https://zakon.rada.gov.ua/laws/show/889-19 [in Ukrainian].

Pro zatverdzhennia Polozhennia pro prokhodzhennia pervynnoi profesiinoi pidhotovky ta pidvyshchennia kvalifikatsii osobamy riadovoho $i$ nachalnytskoho skladu Derzhavnoi kryminalno-vykonavchoi sluzhby Ukrainy [On approval of the Regulations on passing the initial professional training and advanced training by persons of the rank and file staff of the State Criminal Enforcement Service of Ukraine]: nakaz Ministerstva yustytsii Ukrainy № 4091/5 (26.12.2018). Retrieved from https://zakon.rada.gov.ua/laws/show/z1496-18 [in Ukrainian].

Pro zatverdzhennia Polozhennia pro systemu profesiinoho navchannia derzhavnykh sluzhbovtsiv, holiv mistsevykh derzhavnykh administratsii, yikh pershykh zastupnykiv ta zastupnykiv, posadovykh osib mistsevoho samovriaduvannia ta deputativ mistsevykh rad [On approving the Regulations on the system of professional training of civil servants, heads of local state administrations, their first deputies and deputies, officials of local self-government and deputies of local councils]: postanova Kabinetu Ministriv Ukrainy № 106 (06.02.2019). Retrieved from https://zakon.rada.gov.ua/laws/show/1062019-\%D0\%BF [in Ukrainian].

Revenko, I. (2007). Khudozhno-estetychna kompetentnist uchytelia yak pokaznyk yoho profesiinoi kultury [Artistic and aesthetic competence of the teacher as an indicator of his professional culture]. Mystetstvo i osvita [Arts and education], 3, 139-146 [in Ukrainian].

Rudnytska, O. (2005). Pedagogika: zagalna ta mystetska [Pedagogy: general and artistic]. Ternopil: Navchalna knyga [in Ukrainian].

Vitvytska, S. (2003). Pedahohichna spriamovanist yak komponent profesiinoi maisternosti maibutnikh vchyteliv [Pedagogical orientation as a component of future teachers' professional skills]. Visnyk Zhytomyrskoho derzhavnoho pedahohichnoho universytetu im. I. Franka [Bulletin of Zhytomyr State Pedagogical University. I. Franko], 12, 78-81 [in Ukrainian].

Yaremchuk, S. (2001). Profesiino-psykholohichna spriamovanist osobystosti maibutnoho vchytelia [Professional-psychological orientation of the future teacher's personality]. Pedahohika i psykholohiia [Pedagogy and art], 1 (30), 89-97 [in Ukrainian].

\section{HRYTSENKO L.}

Poltava V. G. Korolenko National Pedagogical University

\section{STRASHKO L.}

Poltava University of Economics and Trade

\section{THE RELATIONSHIP OF ART AND GRAPHIC AND PROFESSIONAL-PEDAGOGICAL COMPETENCES IN THE PROCESS OF TRAINING THE TECHNOLOGIES AND DESIGN PROFESSIONALS}

Reforming the national educational field involves the technologicalization (based on theory and practice) of the educational product and the development of professional competences. This trend is confronted with a number of contradictions: the desire to replace traditional approaches in the preparation of specialists for modern and imperfect methodological base; efforts to exploit the achievements of the world's scientific and methodological findings and the lack of 
adapted methodological materials; the desire to increase the competence of specialists and the lack of understanding of the need to take into account the importance of personal factor in this process.

The study is devoted to the study of ways of overcoming the contradictions that actualize the importance of the pedagogical aspect in the preparation of technologies and design teachers. After all, pedagogical competence implies not only professional knowledge, but also requires professional and pedagogical orientation of the future teacher's personality.

The purpose of the article is to investigate the feasibility of considering the relationship of artistic and graphic competence with professional and pedagogical competence in the training of technologies and design specialist.

The irreversibility of the nature of educational changes in society indicates that the process of awareness of the values of pedagogical activity forms a public understanding of the importance of the teaching profession, and it cannot be put on par with other professions. The study of value-oriented pedagogical activity proves that it is impossible to mark the equation between the concepts of competence and qualification. Professional and pedagogical competence is integrated and combines professional knowledge, intellectual skills and specific activities, because professional formation involves the operation of complex models of mental activity, mastering techniques and methods of pedagogical thinking and reflexivity. Defining the phenomenon of professional and pedagogical orientation, it can be argued that it is conceptually important to take into account the factors of motives, interests, needs, abilities to this specific activity.

Artistic-graphic competence is a special psychological formation, which determines the emotional-aesthetic orientation and activity of the individual, his ability to art-figurative development of the environment by means of graphic methods and means, as well as its embodiment in the spiritual plane or subject material.

The study of research materials made it possible to trace the following types of relationships between the investigated phenomena: direct, inverse, static, spatial, temporal, functional, target. At the heart of the suggested model of the relationship of graphic and professional and pedagogical competencies is the methodological way of forming the personality of a specialist from artistic and graphic competence through obtaining a certain level of professional and pedagogical culture (symbiosis of professional knowledge, personal beliefs and professional activity).

The structural-logical model of the interrelation of artistic-graphic and professional-pedagogical competences, suggested by the authors, is the basis of methodological materials for the training of the future specialists in technologies and design. Testing of methodological materials for practical tasks proved the efficiency and correctness of our approach.

Keywords: artistic and graphic competence; professional competence; professional and pedagogical competence; professional and pedagogical orientation

Стаття надійшла до редакції 25.10.2019 р.

УДК 378.22.01.015.31-051:502:[613]

DOI: https://doi.org/10.33989/2075-146x.2019.24.194638

МАРИНА ДЯЧЕНКО-БОГУН

ORCID ID 0000-0002-1209-2120

Полтавський національний педагогічний університет імені В.Г. Короленка

ЛІНА РИБАЛКО

ORCID ID 0000-0001-6092-9442

Полтавський національний технічний університет імені Юрія Кондратюка

\section{ІСТОРИКО-ПЕДАГОГІЧНІ АСПЕКТИ РЕАЛІЗАЦІЇ ЗДОРОВ'ЯЗБЕРЕЖУВАЛЬНИХ ТЕХНОЛОГІЙ У СУСПІЛЬСТВІ.}

\footnotetext{
У статті висвітлюється генезис історичних аспектів а також проводиться аналіз головних тенденцій у розвитку наукових поглядів на збереження здоров'я, виокремленні та обгрунтуванні основних етапів становлення теоретичних концепцій збереження здоров'я людини, ставленні суспільства до проблем здоров'язбереження, які віддзеркалюють динамічний прояв загальнолюдських цінностей і потреб.
}

Ключові слова: здоров'я; здоров'язбережувальні технології; здоров'язбережувальна діяльність; етапи здоров'язбереження

Актуальність проблеми. Вивчення історико-педагогічних джерел, а також питання формування, зміцнення і збереження здоров'я дитини стали об'єктом наукового аналізу для багатьох представників педагогічної науки досить давно. Учені минулого намагалися обгрунтувати теоретико-методичні особливості збереження здоров’я дитини в поєднанні розумового розвитку і фізичного виховання, підкреслювали важливість навчання дитини у відповідності до іiі вікових, розумових, фізичних можливостей і здібностей. В даних умовах особливої актуальності набуває проблема якісної підготовки майбутніх учителів, готових до виховання і формування здорового способу життя, який забезпечить гармонійний розвиток особистості кожної дитини а також окреслить основні аспекти до реалізації здоров'язбережувальних технологій в освіті. 